\title{
The quality of wood pellets used in automatic class 5 Ecodesign boilers on the retail market in the context of air protection in Poland
}

ABSTRACT: Wood pellets, commonly referred to as biomass fuel, are increasingly used in heating and district heating in the European Union countries, including Poland. Their use in class 5 and/or Ecodesign boilers enables an individual consumer to use energy from renewable sources, reduce the environmental burden by reducing the emission of harmful compounds, and provides a sense of comfort by automating the boiler system. The article presents the current situation in the global wood pellet market, describes the basic quality standards applicable to this fuel during production, and indicates the difficulties in the implementation of programs co-financing the replacement of obsolete coal-fired boilers with automatic class 5 biomass-fired boilers. The research presented in this article is focused on the presence of contaminants in the DIN Plus, EN Plus, and A1 pellets, as well as in non-certified pellets. The analysis has shown that the use of wood pellets containing

\footnotetext{
${ }^{1}$ Department of Geochemistry, Mineralogy and Petrography, Faculty of Earth Sciences, University of Silesia in Katowice, P.P.U.H. Zamech Zygmunt Nocon, Czeladź, ORCID: 0000-0003-0594-2366; e-mail: marta@zamech-czeladz.pl

${ }^{2}$ Department of Geochemistry, Mineralogy and Petrography, Faculty of Earth Sciences, University of Silesia in Katowice, P.P.U.H. Zamech Zygmunt Nocon, Czeladź, ORCID: 0000-0003-3745-114X.

${ }^{3}$ Mineral and Energy Economy Research Institute of the Polish Academy of Sciences, Kraków, ORCID: 00000003-4897-9142.

${ }^{4}$ Department of Geochemistry, Mineralogy and Petrography, Faculty of Earth Sciences, University of Silesia in Katowice, ORCID: 0000-0002-9876-9007.

${ }^{5}$ Department of Geochemistry, Mineralogy and Petrography, Faculty of Earth Sciences, University of Silesia in Katowice, GGS-PROJEKT Laboratory of geology and environmental protection Sp. z o. o., Chorzów, ORCID: 00000001-5055-6435.
} 
prohibited substances negatively affects boiler operation and contributes to the formation of slag and the emission of harmful compounds, making the discussed fuel non-ecological.

KEYWORDS: biomass, wood pellet, quality of pellets, class 5 boilers

\section{Introduction}

Biomass is the most important renewable energy source in the world. Figure 1 shows the share of individual energy carriers used for energy purposes in 2016. It should be noted that the share of biomass is $14 \%$. Hydropower, geothermal, wind, and solar energy (the share of wave energy and tidal waves was $0.005 \%$ and was not presented in the graph) account for the remaining 4\% (WBA 2018). Biomass for energy purposes includes many types of biogenic substances of vegetable and animal origin, from which solid, liquid, and gas fuels can be produced (Mirowski et al. 2018). Wood pellets are the most popular in the world market.

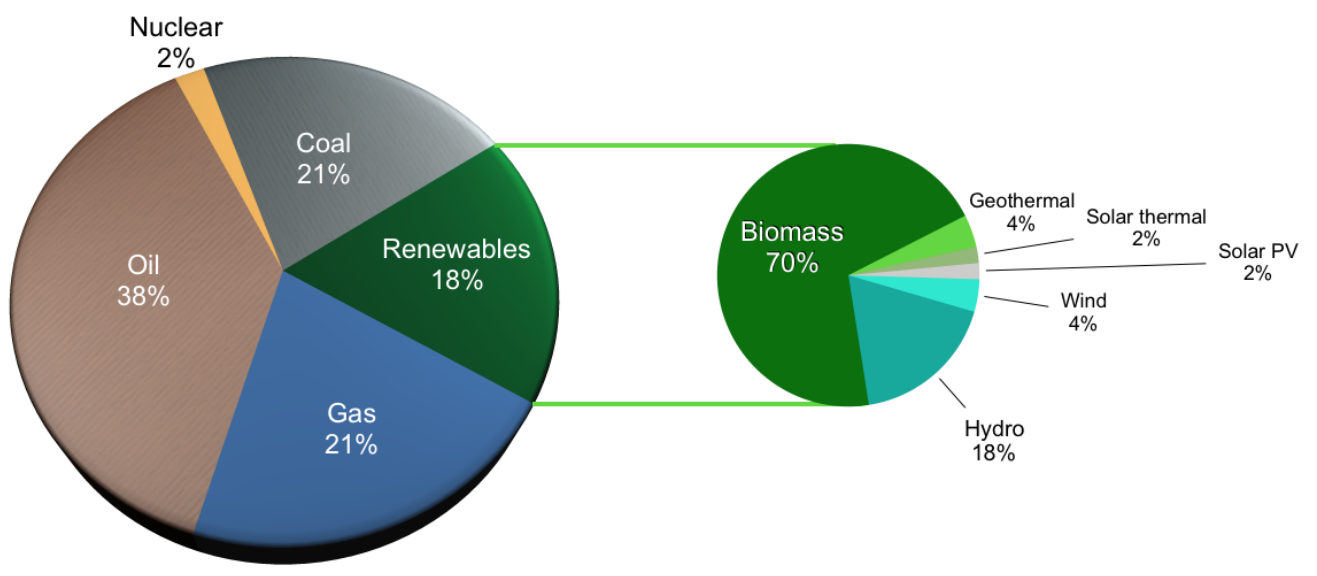

Fig. 1. The share of energy carriers in the global gross energy consumption in 2016 (WBA 2018)

Rys. 1. Udział nośników energii w światowym zużyciu energii brutto w 2016 roku

The history of wood pellet production begins with the oil crisis in the 1970s. The technology of wood pellet production is based on the animal feed production. Efforts to create an alternative fuel produced from renewable sources (biomass) to replace heating oil resulted in setting the quality standards for this fuel and its introduction to international markets. After the end of the oil crisis, the production of wood pellets decreased globally. Since the 1990s, when the problems of global warming, climate change, and depleted fossil fuels were globally recognized, wood pellets have become an alternative to expensive natural gas, heating oil, and high-emission coal. 
The article presents the qualitative analysis of selected wood pellets, available in the domestic retail market, designed for automatic boilers. The differences in the qualitative composition determined during the analysis have confirmed that pellet producers engage in unfair practices that affect heating devices, where contaminated wood pellets cause harmful compounds to be emitted during combustion, while the ash forms slags and contains compounds preventing its use as a fertilizer.

\section{The pellet market and its use}

Figure 2 presents the volumes of wood pellet production in 2016 and the directions of import/ export. The largest producer and consumer of this energy carrier is the European Union. According to the report of the European Biomass Association from 2018, the EU-28 consumed 24.1 million Mg of wood pellets in 2017 (Bioenergy Europe 2018). In 2016, power plants consumed $38.3 \%$ of wood pellets for electricity generation. However, most of this fuel was used for heat production: in households $(42.6 \%)$, commercial sector $(11.8 \%)$, and in CHP units $(7.3 \%)$ (Bioenergy Europe 2018).

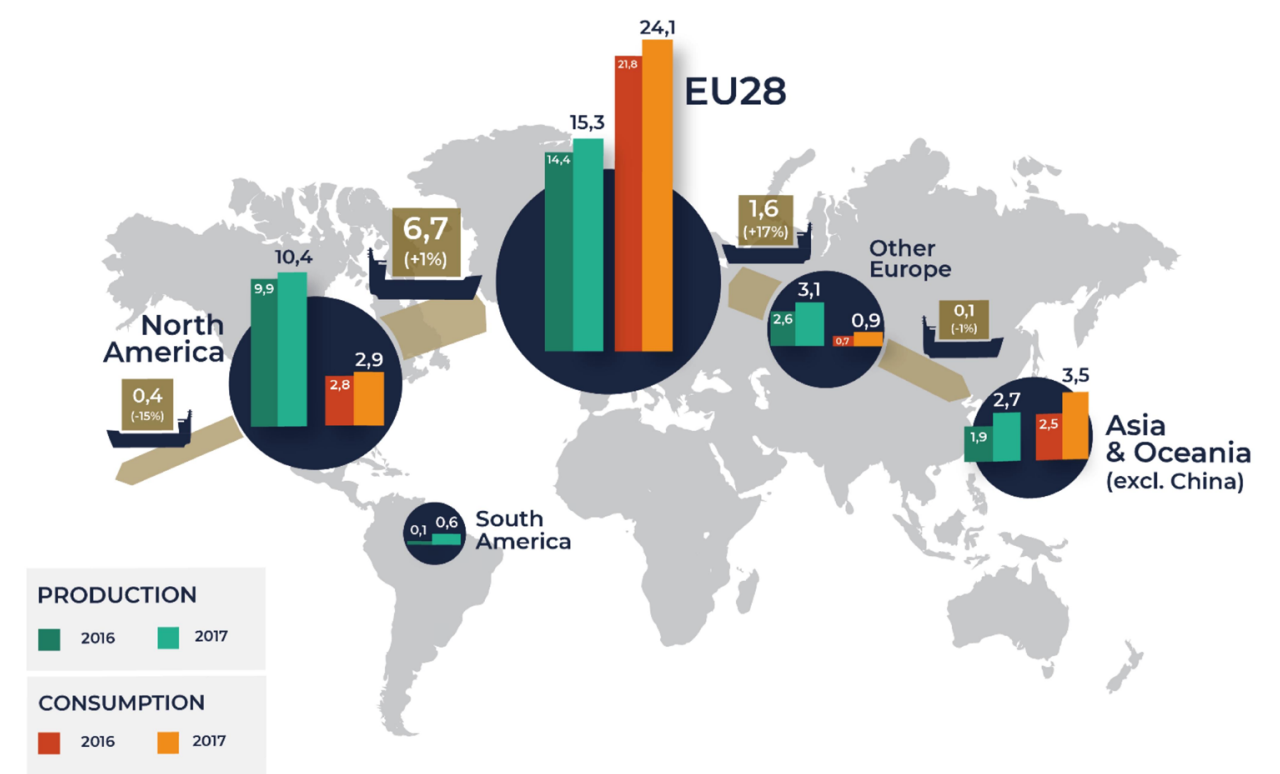

Note: Ireland, Japan, New Zealand, and Ukraine: 2017 production is a replication of 2016; Belgium: 2017 production estimated by EPC; Romania: production estimated by EPC

Fig. 2. Global production, consumption, and trade of wood pellets in 2016-2017, Mt (Bioenergy Europe 2018)

Rys. 2. Światowa produkcja, zużycie i handel pelletem drzewnym w latach 2016-2017 (w mln Mg) 
Wood pellets enable boiler manufacturers to design heating devices achieving high standards of low-emission heating devices adopted in the Ecodesign Directive (Ecodesign Directive 2015). The production of such fuel is not complicated. The input material in the form of sawdust (preferably from deciduous trees) must be clean. In addition, the appropriate level of moisture content is required. The wood pellet market is growing at a rapid pace. Unfortunately, in such cases, despite the clear rules of standardization and normalization of this fuel, there are cases of fraud on the market. According to Bioenergy Europe 2018, there were 55 companies producing wood pellets with a total production capacity of 1.2 million tons/year in 2017 in Poland.

\section{Quality standards for wood pellets}

The PN - EN ISO 17225 - 2 standard (ISO_standard 2014) organizes wood pellets according to the following classes: A1 - the highest quality pellets for use in household boilers and furnaces, A2 - pellets for less demanding installations; B - pellets made of unprocessed wood without heavy metals. Pellets meeting the DIN Plus and/or EN Plus A1 standards are the most popular in both domestic and foreign markets.

Due to the ever-increasing problem of environmental pollution and greater consumer awareness, pellet boilers are becoming increasingly popular. Based on the Directive (EU) 2016/2284 of the European Parliament and of the Council of 14 December 2016 on the reduction of national emissions of certain atmospheric pollutants, amending Directive 2003/35/EC and repealing Directive 2001/81/EC, Member States are obliged to implement air quality control programs (Directive 2016).

Thanks to these changes, low-stack emission reduction programs were launched in the Member States, including Poland. The Lesser Poland Province (Mirowski and Maczuga 2017), followed by the Silesian Province, were the first to introduce such programs. The question of environmental protection and the reduction of low-stack emissions is discussed not only at the local but also at the national level. An analysis of air quality is carried out in Poland every year. Twelve of the continuously monitored pollutants include: sulfur dioxide, nitrogen dioxide, carbon monoxide, benzene, ozone, PM10, PM2.5, and elements determined in PM10: lead, arsenic, cadmium, nickel, and benzo (a) pyrene. In the winter season, the issue of smog is the recurring theme. It is inseparably connected with the heat demand, and thus with the combustion process. Household heating is responsible for $88.21 \%$ of PM10 concentrations exceeding the daily limit value (annual average value $-40 \mu \mathrm{g} / \mathrm{m}^{3}$ ), while the industry contributes $1.84 \%$. Central heating in households is the main source of low-stack emissions. This is related to the use of boilers and fuels not meeting the quality requirements.

With the ever increasing problem of smog and greater social awareness, numerous funds have been established in order to reduce low-stack emissions. Municipalities, under the framework of operational programs, can apply for co-financing the purchase of biomass boilers 
and; thus, it is possible to replace boilers with environmentally-friendly ones. The boilers co -financed by the European Union must meet the requirements of the $5^{\text {th }}$ class according to the EN 303-5-2012 standard and Eco-design requirements (according to the Commission Regulation (EU) 2015/1189 of 28 April 2015 implementing Directive 2009/125/EC of the European Parliament and of the Council with regard to Ecodesign requirements for solid fuel boilers (KPOP 2015). Fully automatic pellet boilers completely meet these requirements; many of them are not only class 5 boilers, but also Ecodesign boilers. The Ecodesign requirements, confirmed by the Ecodesign certification are currently the most restrictive standards for solid fuel boilers.

As of 1 January 2020, solid fuel boilers placed on the market and in use will have to meet the energy efficiency and pollutant requirements for seasonal heating provided by the provisions of the Commission Implementing Regulation of Directive 2009/125/EC of 21 October 2009 laying down the general principles for the definition of Ecodesign requirements (KPOP 2015). Both in the case of class 5 and Ecodesign boilers, the emissions of particulate matter shall not be higher than $40 \mathrm{mg} / \mathrm{m}^{3}$ at $40 \mathrm{mg} / \mathrm{m}^{3}$ (Ecodesign Directive 2015). However, only Ecodesign boilers ensure compliance with emission standards during operation at lower loads. This is important because boilers rarely operate at full power. At lower load, the combustion conditions are worse, resulting in higher dust and carbon monoxide emissions. Compared to the requirements of the PN-EN 303-5:2012 (Standard 2012), the Ecodesign requirements introduce the need to verify seasonal efficiency and the emission of pollutants, which takes operation below the nominal power of the boiler into account.

It is not possible to solve the problem of low-stack emissions at the level of properly selected and certified top-class boilers. Ecological pellet boilers may not fulfill their function and contribute to the reduced emission of pollutants if the fuel used does not meet the quality standards. It is possible to precisely determine the physicochemical values of pellets, i.e. the content of: hydrogen, nitrogen, chlorine, ash, and moisture content according to the popular European EN Plus ${ }^{\circledR}$ certification (ENplus 2019). With the increasing production of non-certified pellets, the authors of this work decided to analyze pellets based on petrographic examination, typically used in fossil fuel analysis (Stach et al. 1982).

\section{Research material and analytical methods}

The authors decided to analyze wood pellets available to individual customers. Wood pellet samples were collected from producers or were purchased in hypermarkets. These included pellets meeting the DIN Plus and/or EN Plus A1 standards, as well as those without these certificates. The purchased fuel was stored in its original packaging (bags) with a capacity of $15 \mathrm{~kg}$ and bearing a label containing the name and address of the manufacturer. In the case of pellets meeting the DIN Plus and/or EN Plus A1 standards, the certification was on the packaging. 
From each packaging that was quartered, $0.5 \mathrm{~kg}$ of averaged material was isolated, from which five preparations were prepared in the next stage according to PN-ISO 7404-2-2005 (PN-ISO 2005). The samples were analyzed using a Zeiss Axio Imager M2m polarization microscope in white light and reflected light using immersion oil. The mineral matter, stone powder, plastic, rust, glass, coal, coal tar, coke, slag, crude oil, metals, and biomass content were analyzed.

In order to standardize the combustion conditions, wood pellets were burnt in pellet boilers with a nominal power of $25 \mathrm{~kW}$. Each sample was burnt in the FOREST boiler (Fig. 3). The boiler, examined by an accredited testing laboratory, meets the class 5 requirements according to the EN 303-5:2012 standard and Ecodesign requirements according to Commission Regulation (EU) 2015/1189 of 28 April 2015 implementing Directive 2009/125/EC of the European Parliament and of the Council with regard to ecodesign requirements for solid fuel boilers (Ecodesign Directive 2015). The boiler technical data is presented in Tables 1 and 2. The analysis presented in this article was carried out in the P.P.U.H Zamech Laboratory of Combustion of Solid Fuels.

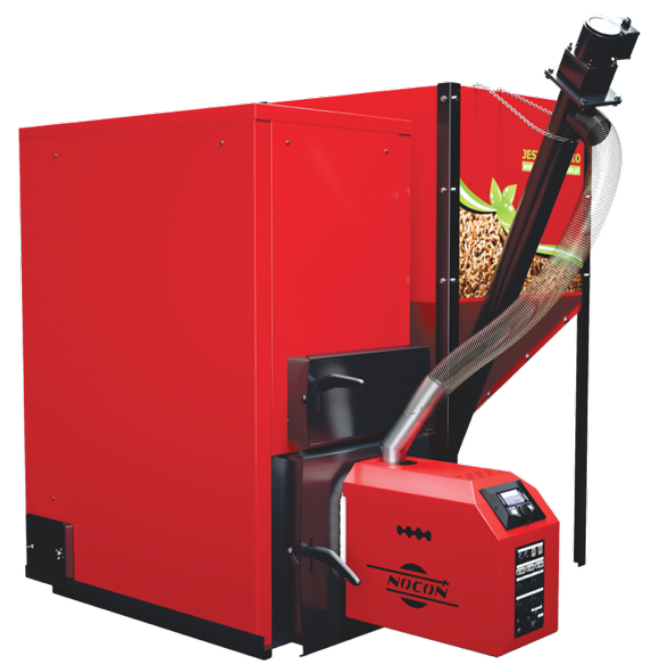

Fig. 3. The FOREST pellet-fueled boiler

Rys. 3. Kocioł pelletowy FOREST

The ash resulting from the combustion of all of the analyzed pellets, in an amount of about $0.2 \mathrm{~kg}$ per sample, was used for the preparation of polished sections. The preparations were subjected to microscopic analysis using a Zeiss Axio Imager M2m microscope in polarized white reflected light using immersion oil. The tests were carried out in accordance with the classification of the International Committee for Coal and Organic Petrology (ICCP) (Suárez-Ruiz et al. 2008, 2017) and allowed such components as: inorganic compounds, metals, non-metals, mineral matter, sinters, sand grains, and organic components, to be determined. 
TABLE 1. Technical data of the FOREST boiler and the requirements of the EN 303-5:2012 standard

TABELA 1. Dane techniczne kotła FOREST w odniesieniu do normy EN 303-5:2012

\begin{tabular}{|l|c|c|c|c|}
\hline \multicolumn{1}{|c|}{ Parameter } & Unit & \multicolumn{2}{c|}{ Value } & Criteria EN 303-5:2012 \\
\hline Energy efficiency & $\%$ & \multicolumn{2}{c|}{$93.5-95.5$} & $\geq 88.4$ \\
\hline \multicolumn{5}{|c|}{ Emission of pollutants [Mg/year] } \\
\hline Element & Unit & Rated power & Minimal power & Value \\
\hline CO & $\mathrm{mg} / \mathrm{m}^{3}$ & 179.4 & 260.5 & $\leq 500$ \\
\hline Gaseous organic pollutants & $\mathrm{mg} / \mathrm{m}^{3}$ & 1.8 & 5.6 & $\leq 20$ \\
\hline Dust & $\mathrm{mg} / \mathrm{m}^{3}$ & 96.3 & - & $\leq 40$ \\
\hline
\end{tabular}

TABLE 2. Technical data of the FOREST boiler and the requirements of Commission Regulation (EU) 2015/1189

TABELA 2. Dane techniczne kotła FOREST w odniesieniu do Rozporządzenia UE 2015/1189

\begin{tabular}{|c|l|c|c|c|}
\hline \multicolumn{2}{|c|}{ Parameter } & Unit & Value & Criteria 2015/1189 \\
\hline \multicolumn{2}{|c|}{ Seasonal energy efficiency } & $\%$ & 85.2 & $\geq 77$ \\
\hline \multirow{3}{*}{$\begin{array}{c}\text { Seasonal } \\
\text { emissions }\end{array}$} & gaseous organic pollutants & $\mathrm{mg} / \mathrm{m}^{3}$ & 5 & $\leq 20$ \\
\cline { 2 - 5 } & $\mathrm{CO}$ & $\mathrm{mg} / \mathrm{m}^{3}$ & 248 & $\leq 500$ \\
\cline { 2 - 5 } & $\mathrm{NO}_{\mathrm{x}}$ & $\mathrm{mg} / \mathrm{m}^{3}$ & 186 & $\leq 200$ \\
\cline { 2 - 5 } & dust & $\mathrm{mg} / \mathrm{m}^{3}$ & 25 & $\leq 40$ \\
\hline
\end{tabular}

\section{Research results}

The petrographic analysis of both pellet and ash (resulting from the combustion process) samples has confirmed unacceptable, according to the PN-EN 1860-2-1006 standard, organic inclusions (Nocoń et al. 2018). A quantitative summary is presented in Table 3.

According to the obtained data, the group of unacceptable components included: glass, slag, rust, metal pieces, mineral matter, stone powder, plastics, and polymers of inorganic origin. The impurities have also been determined in a certified pellet (DIN Plus and/or EN Plus A1 certifications).

The percentage of contaminants determined by planimetry was the highest in the case of sample No. 18.222. The biomass from this sample came from a producer without any certificate and contained as much as $2.9 \%$ of mineral matter. The comparison of the results of the analysis of pellet samples with the results of ash analysis gives unambiguous results. Based on petrographic analysis, it can be stated that the most contaminated pellet (sample No. 18.222) subjected to the combustion process (sample No. 18.223) shows the highest concentrations of inorganic chemi- 
cal compounds. Out of five analyzed burnt biomass samples, only one polished section, namely sample No. 18.233, was free from such contaminants as: sinters, silica, and sand grains, while the content of metals (iron, rust) was at the level of $2.4 \%$ (Jelonek et al. 2018). The percentage share of individual components is summarized in Table 4.

TABLE 3. The share of components of wood pellet samples [\%]

TABELA 3. Udział ilościowy badanych składników występujących w próbkach pelletów drzewnych oraz ich identyfikacja [\%]

\begin{tabular}{|c|c|c|c|c|c|c|c|c|c|c|c|c|}
\hline No. & 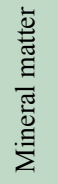 & 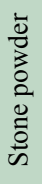 & 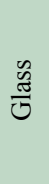 & $\begin{array}{l}\stackrel{\tilde{U}}{\tilde{n}} \\
\frac{\tilde{\sigma}}{2}\end{array}$ & 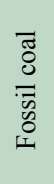 & $\frac{\text { పే }}{\text { चूँ }}$ & $\frac{\mathscr{y}}{0}$ & $\begin{array}{l}\frac{50}{\omega} \\
\frac{\pi}{\omega}\end{array}$ & $\begin{array}{l}\bar{\sigma} \\
\tilde{D} \\
\bar{J} \\
\tilde{J}\end{array}$ & $\underset{\widetilde{n}}{\tilde{2}}$ & $\frac{\frac{n}{\pi}}{\sum^{\frac{\pi}{0}}}$ & 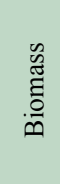 \\
\hline 18.203 & 1.0 & 0 & 0 & 0 & 0.3 & 0 & 0 & 0 & 0 & 0 & 0.5 & 98.2 \\
\hline 18.206 & 0.8 & 0 & 0 & 0.1 & 0.1 & 0 & 0 & 0 & 0 & 0 & 0.5 & 98.5 \\
\hline 18.208 & 0.2 & 0 & 0 & 0 & 0.7 & 0 & 0 & 0 & 0.1 & 0 & 0.9 & 98.1 \\
\hline 18.210 & 0.6 & 0 & 0 & 0 & 0.1 & 0 & 0 & 0 & 0 & 0 & 1.4 & 97.9 \\
\hline 18.222 & 2.9 & 0 & 0 & 0.1 & 0.6 & 0 & 0 & 0 & 0 & 0.2 & 0.3 & 95.9 \\
\hline
\end{tabular}

Source: Nocoń et al. 2018.

TABLE 4. The share of components of wood ash samples [\%]

TABELA 4. Udział ilościowy badanych składników występujących w próbkach popiołów drzewnych oraz ich identyfikacja [\%]

\begin{tabular}{|c|c|c|c|c|c|c|}
\hline No. & Metals & Mineral matter & $\mathrm{SiO}_{2}$ & Sinters & $\begin{array}{c}\text { Organic } \\
\text { contaminants }\end{array}$ & $\begin{array}{c}\text { Unburned } \\
\text { biomass }\end{array}$ \\
\hline 18.204 & 8.8 & 40.4 & 18.4 & 17.2 & 9.2 & 6.0 \\
\hline 18.205 & 1.6 & 50.4 & 10.4 & 29.6 & 5.6 & 2.4 \\
\hline 18.207 & 2.0 & 51.2 & 3.2 & 32.8 & 8.0 & 2.8 \\
\hline 18.209 & 2.8 & 33.6 & 11.2 & 29.2 & 23.2 & 0.0 \\
\hline 18.223 & 2.4 & 95.6 & 0.0 & 0.0 & 2.0 & 0.0 \\
\hline
\end{tabular}

Source: Jelonek et al. 2018.

Both organic and inorganic parts, which were determined during petrographic analysis and presented in the images (Figs. 4, 5 and 6) are reflected in the combustion process, which involves: the dose of fuel, the time needed for its combustion, and the air delivery system. If the biomass combustion process takes place in unfavorable conditions, it may have a negative impact on the environment. The devices used in distributed heating systems do not always ensure the correct combustion process. Even if the boiler meets the PN-EN 303-5:2012 standard and has a certificate or an ecological label of an independent accredited research center, the efficiency 
and emission rates stated by the manufacturer may not be reached due to the improper use of the boiler (Nitzche 2016).

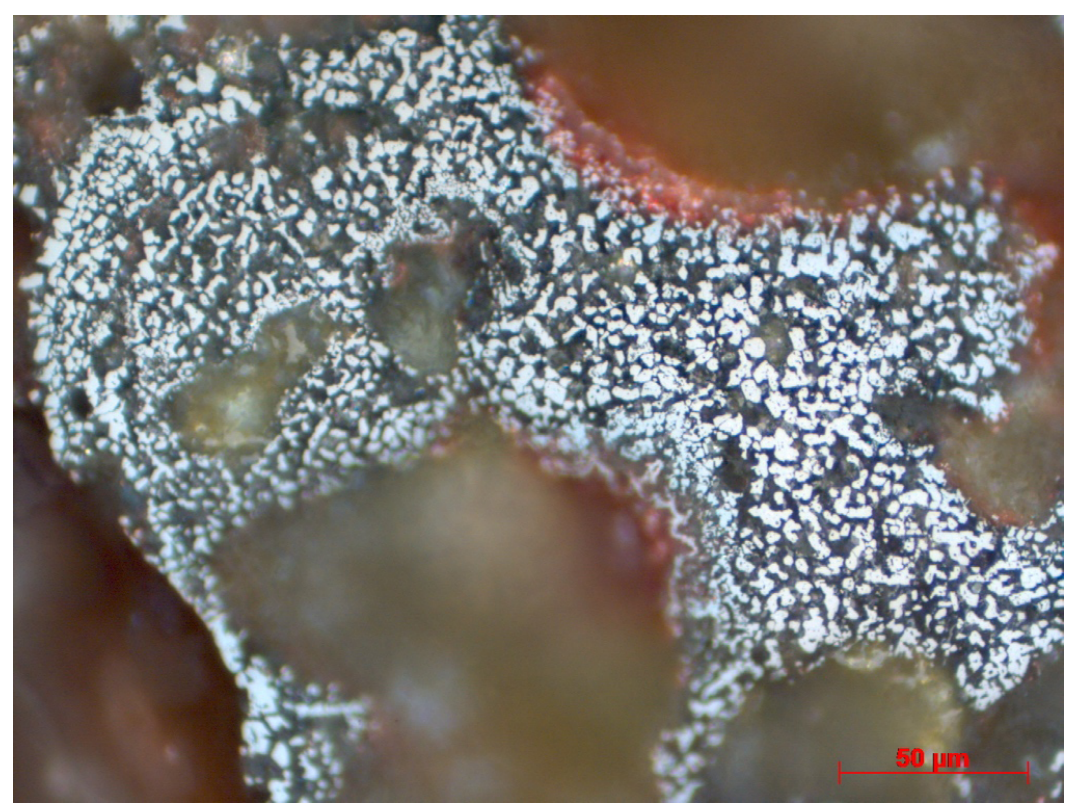

Fig. 4. Metals and rust in the examined ash samples, microscopic image (Jelonek et al. 2018) Rys. 4. Metale i rdza w badanych próbkach popiołów, obraz mikroskopowy

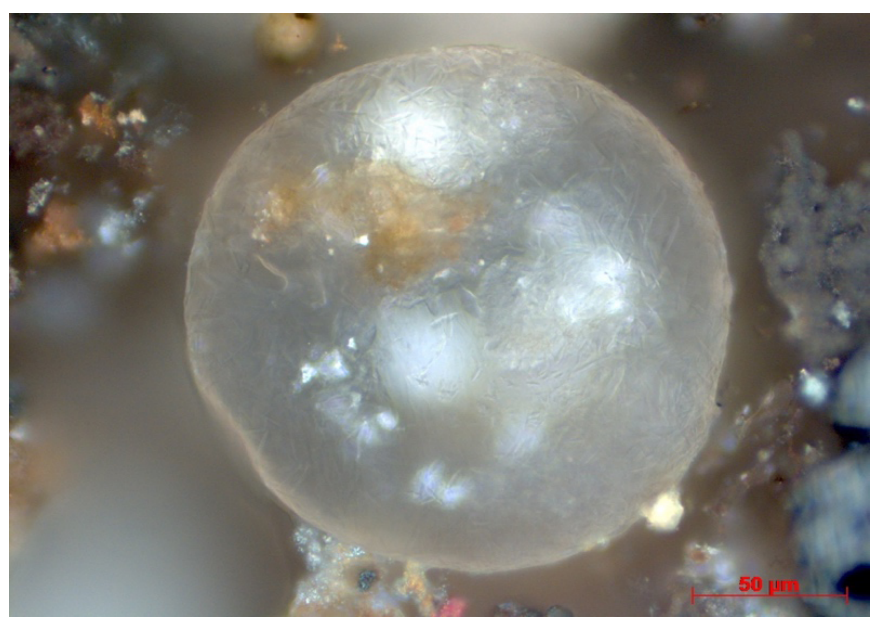

Fig. 5. Sand grains and molten silica in the examined ash samples, microscopic image (Jelonek et al. 2018)

Rys. 5. Ziarna piasku, stopiona krzemionka w badanych próbkach popiołów, obraz mikroskopowy 

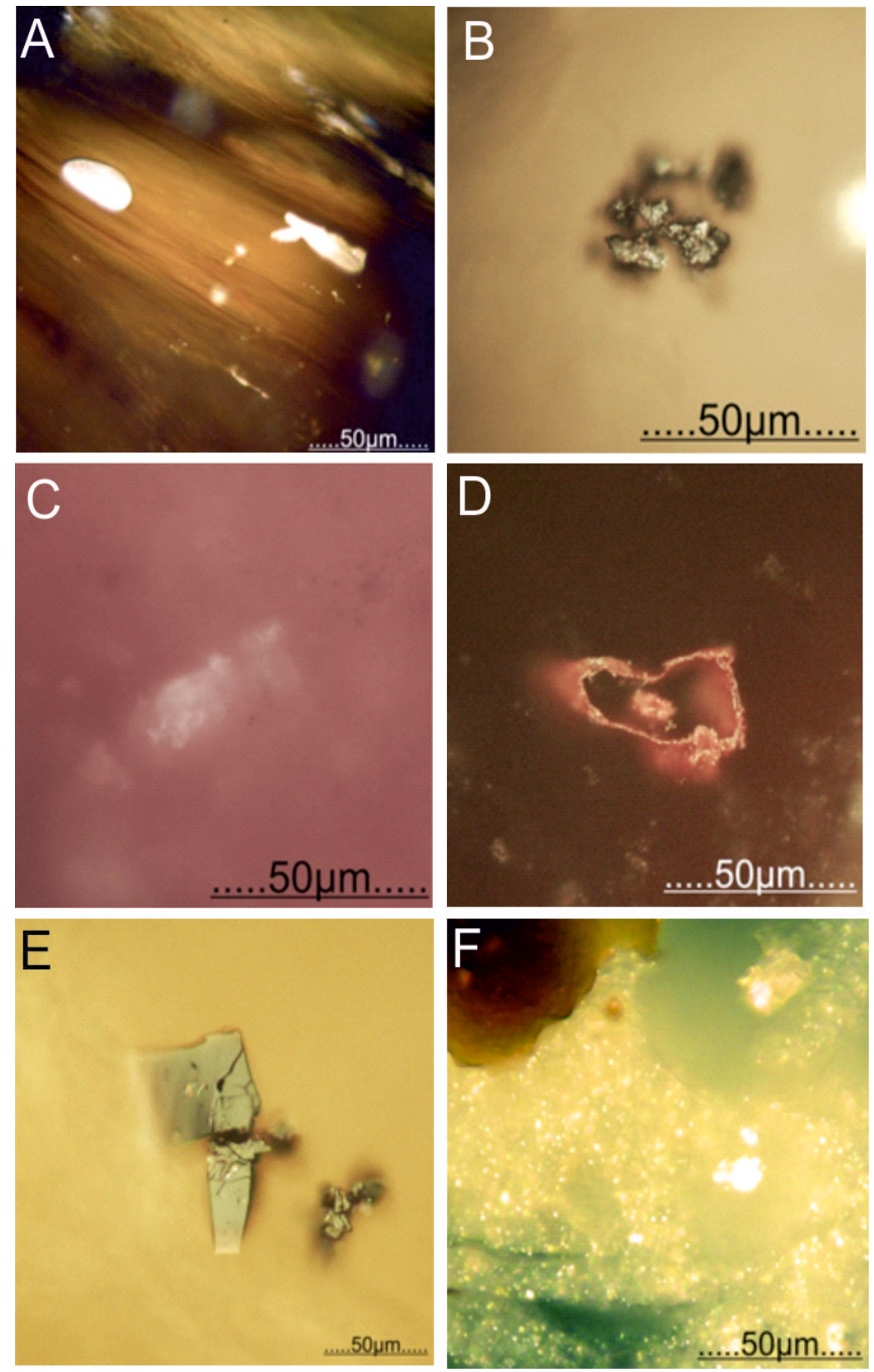

Fig. 6. The contamination identification based on wood pellet sample No. 18.222, reflected light A - biomass (wood pellets); impurities: B - metal residue; $\mathrm{C}$ - plastic; D - rust; E - coal; F - mineral matter (Nocoń et al. 2018)

Rys. 6. Identyfikacja kontaminacji na przykładzie próbki 18.222 pelletu drzewnego w świetle odbitym A - biomasa (pellet drzewny); zanieczyszczenia: B - metal; C - tworzywo sztuczne; D - rdza; E - węgiel; $\mathrm{F}$ - materia mineralna 


\section{Summary and conclusions}

No unburned biomass in sample No. 18.223 proves that the boiler settings for the combustion process were well-matched to the raw material. Preliminary assumptions regarding the combustion parameters have been confirmed by petrographic analysis. This, in turn, has been confirmed by the information on the place of combustion of the raw material designated with sample No. 18.222. The discussed pellet was subjected to the combustion process at the boiler manufacturer's site using the adjusted and serviced boilers. The proper adjustment of the FOREST boiler enabled the complete combustion of the contaminated pellets while the content of sinters and $\mathrm{SiO}_{2}$ remained at the level of $0 \%$.

After the combustion process, all contaminants in the pellet, i.e. plastics $(0.1 \%)$, fossil coal $(0.6 \%)$, rust $(0.2 \%)$, and metals $(0.3 \%)$, contaminated the flue gas. This resulted in an increase in the emission of harmful substances. The conducted research and analysis confirm the fact that the combustion of uncertified pellets in households directly contributes to the increase in concentrations of harmful pollutants; meanwhile, the resulting ash contains compounds preventing its use as a fertilizer.

System solutions based on EU (Regional Operational Programs) and national funds (e.g. The Clean Air Program) unfortunately do not solve the problem of using unsuitable fuels in eco -friendly pellet heating devices. Furthermore, they allow the use of class A2 (pellets with higher ash content designed for high-power devices) or B pellets (industrial pellets). Commune offices rely on EU subsidies under the Regional Operational Program. In the case of tenders aimed at modernizing boiler houses, the subcontractor is obliged to provide a class 5 boiler with energy efficiency and emission efficiency in accordance with the PN-EN 303-5:2012 standard or with the Ecodesign certification. However, under the same tender conditions, the boiler should have a burner equipped with a system for efficient slag removal, enabling the combustion of A1, A2, and B class pellets (Project 2017). Similar provisions also appear when the EU funds are used in other municipalities. The order of the investor (municipality) concerns the delivery of a class 5 boiler (or equivalent) according to Commission Regulation (EU) 2015/1189 of 28 April 2015 implementing Directive 2009/125/EC of the European Parliament and of the Council. The project envisages the use of automatic central heating boilers fired with biomass in the form of wood chips or pellets in the: A1, A2, or B class (DTI 2018).

The solution to the problem of low-stack emissions and smog, in order to be effective and long-term, should include not only replacing the boiler with an environmentally-friendly one, but also an obligation to use household fuels of the highest quality, i.e. certified A1 class pellets.

The use of class A2 or B pellets is economically viable for the user. However, as shown in this publication, it can cause problems when a boiler is adapted only for A1 class wood pellets. Boiler manufacturers are also investigating the possibility of using non-wood biomass pellets (agro) (Mirowski 2016; Niemczyk et al. 2018; Mudryk et al. 2018). 
The change of programs co-financing the modernization of boiler houses and relatively low investments in measuring sensors would allow municipal units to monitor the emission of pollutants, which would eliminate the use of low-quality fuels.

\section{References}

Bioenergy Europe 2018. Pellet Report. Brussels. [Online] https://epc.bioenergyeurope.org/bioenergy-europe-pellet-report-2018/ [Accessed: 2019-01-05].

Directive 2016. Directive(EU) 2016/2284 of the European Parliament and of the Council of 14 December 2016 on the Reduction of National Emissions of Certain Atmospheric Pollutants, Amending Directive 2003/35/EC and Repealing Directive 2001/81/EC.

DTI. 2018. Support for distributed power generation in the Bieszczady communes through the installation of renewable energy systems for households, ordering party: Ustrzyki Dolne. Technical documentation of biomass boilers with a capacity of $15-45 \mathrm{~kW}$ (Wsparcie energetyki rozproszonej $w$ gminach bieszczadzkich przez instalacje systemów energii odnawialnej dla gospodarstw domowych zamawiajacy gmina Ustrzyki Dolne. Dokumentacja techniczna instalacji kottów na biomasę o mocy 15-45 kW). [Online] http://www.bip.ustrzyki-dolne.pl/index.php?page=position2.php\&id=5924\&grp=34 [Accessed: 2019-01-05] (in Polish).

Ecodesign Directive 2015. Commission Regulation (EU) 2015/1189 of 28 April 2015 Implementing Directive 2009/125/EC of the European Parliament and of the Council with Regard to Ecodesign Requirements for Solid Fuel Boilers.

ENplus. 2019. ENplus ${ }^{\circledR}$ Handbook (v3.0). [Online] https://enplus-pellets.eu/en-in/resources-en-in/technical-documentation-en-in.html\#handbook [ Accessed: 2019-01-05].

ISO Standard 2014. PN-EN ISO 17225-2:2014 Solid biofuels - fuel specifications and classes - Part 2: Graded wood pellets (PN-EN ISO 17225-2:2014-07 Biopaliwa state - specyfikacje paliw i klasy Część 2: Klasy peletów drzewnych). [Online] http://sklep.pkn.pl/pn-en-iso-17225-2-2014-07p.html [Accessed: 2019-01-05] (in Polish).

JELONEK et al. 2018 - JeloneK, Z., NoCoŃ, A., JELONEK, I. and JACH-NoCoŃ, M. 2018. The determination of contaminants in ashes produced after the combustion of wood pellets using optical petrography (Identyfikacja zanieczyszczeń wystęujacych w popiołach powstałych po spaleniu pelletów drzewnych metoda petrografii optycznej). Zeszyty Naukowe Instytutu Gospodarki Surowcami Mineralnymi i Energia Polskiej Akademii Nauk No. 105, pp. 135-146, DOI: 10.24425/124373 (in Polish).

KPOP. 2015. National program for air protection until 2020 (Krajowy program ochrony powietrza do roku 2020). Warszawa. [Online] https://www.mos.gov.pl/g2/big/2015_09/e1dcdab8f1749936fd2ef53aefc3a7ba.pdf [Accessed: 2019-01-05] (in Polish).

MirowsKi, T. and MACZUGA, R. 2017. Legal regulation in the household sector in Poland on the use of solid fuels and boilers up to $500 \mathrm{~kW}$ (Regulacje prawne $w$ sektorze gospodarstw domowych w Polsce $w$ zakresie użytkowania paliw stałych i kottów do $500 \mathrm{KW}$ ). Zeszyty Naukowe Instytutu Gospodarki Surowcami Mineralnymi i Energia Polskiej Akademii Nauk No. 97, pp. 33-42. [Online] https://meeri. eu/Wydawnictwa/ZN97/mirowski-maczuga.pdf [Accessed: 2019-01-05] (in Polish).

MirOWSKI et al. 2018 - MirowsKi, T., MOKRZYCKI, E. and UliASZ-BOCHEŃCZYK, A. 2018. The energy use of biomass (Energetyczne wykorzystanie biomasy). Publishing House of the MEERI PAS, Kraków. [Online] https://min-pan.krakow.pl/wydawnictwo/wp-content/uploads/sites/4/2019/01/biomasa-2018. pdf [Accessed: 2019-02-25] (in Polish). 
MIROWSKI, T. 2016. Utilization of biomass for energy purpose versus reduction of emission of air pollutants from municipal and households sector (Wykorzystanie biomasy na cele grzewcze a ograniczenie emisji zanieczyszczeń powietrza z sektora komunalno-bytowego). Rocznik Ochrona Środowiska 18(1), pp. 466-477. [Online] https://www.scopus.com/inward/record.uri?eid=2-s2.0-85032452678\&partner$\mathrm{ID}=40 \& \mathrm{md} 5=2 \mathrm{c} 57598 \mathrm{ccb} 8302 \mathrm{dba77d} 42 \mathrm{f} 38 \mathrm{c} 6 \mathrm{c} 3 \mathrm{e} 4 \mathrm{f}$ [Accessed: 2019-02-15].

Mudryk et al. 2018 - Mudryk, K., Wróbel, M., Jewiarz,M., Pelczar,G. and Dyjakon, A. 2018. Innovative Production Technology of High Quality Pellets for Power Plants. [In:] Renewable Energy Sources: Engineering, Technology, Innovation, edited by Krzysztof Mudryk and Sebastian Werle, pp. 701-712. Cham: Springer International Publishing.

NiemCZYK et al. 2018 - NiemCZYK, M., KAliszewski, A., Jewiarz, M., WróBel, M. and MudryK, K. 2018. Biomass and Bioenergy Productivity and Biomass Characteristics of Selected Poplar (Populus Spp.) Cultivars under the Climatic Conditions of Northern Poland. Biomass and Bioenergy 111 (February). Elsevier Ltd., pp. 46-51. DOI:10.1016/j.biombioe.2018.02.002.

NITZCHE, M. 2016. Identification of a small scale wood pellet boiler for control design (Identyfikacja kotła małej mocy opalanego peletem drzewnym dla celów sterowania). Politechnika Opolska. [Online] https://we.po.opole.pl/dmdocuments/autoreferat/Nitsche/Autoreferat_Nitsche.pdf [Accessed: 2019-0215] (in Polish).

NoCOŃ et al. 2018 - NoCOŃ A., JACH-NoCOŃ M. and JELONEK, I. 2018. The preliminary studies on the wood pellets combustion in pellet-fired domestic boilers. Zeszyty Naukowe Instytutu Gospodarki Surowcami Mineralnymi i Energia Polskiej Akademii Nauk No. 104, pp. 131-140, DOI: 10.24425/124372.

PN-ISO. 2005. PN ISO 7404-2: 2005 Methods for the petrographic analysis of bituminous coal and anthracite - Part 2: Method of preparing coal samples (PN-ISO 7404-2:2005 Metody analizy petrograficznej węgla kamiennego (bitumicznego) i antracytu - Część 2: Metoda przygotowania próbek węgla). [Online] http://sklep.pkn.pl/pn-iso-7404-2-2005p.html [Accessed: 2019-02-15] (in Polish).

Project 2017. Detailed design of biomass boilers with a capacity of $15-25 \mathrm{~kW}$ - investor: Potok Wielki Municipality (Projekt wykonawczy zbiorczy instalacji kotłów na biomasę o mocy 15-25 $\mathrm{kW}-$ inwestor gmina Potok Wielki). [Online] https://ugpotokwielki.bip.lubelskie.pl/upload/pliki/0Zal._Nr_1_do_ SIWZ_-_Dokumentacje_techniczne_kotlow_na_biomase.pdf [Accessed: 2019-02-15] (in Polish).

Stach et al. 1982 - Stach, E., Mackowsky, M-Th., TAYlor, G.H., Chandra, D., Teichmuller, M. and Teichmuller, R. 1982. Stach's Textbook of Coal Petrology. Gebruder Borntraeger; $3^{\text {rd }}$ Revised $\&$ enlarged edition.

Standard 2012. PN-EN 303-5:2012 Heating boilers. Heating boilers for solid fuels, manually and automatically stoked, nominal heat output of up to $500 \mathrm{KW}$. Terminology, requirements, testing and marking.

SuÁrez-Ruiz et al. 2008 - SuÁrez-Ruiz, I., VAlentim, B., Bouzinos, A., Flores, D., Gómez, B. A., KAlaitZidis, S. and PredeAnU, G. 2008. Towards an ICCP Classification of Fly Ash Components. The Society of Organic Petrology (TSOP) Newsletter 25 (January), pp. 10-13.

SuÁreZ-Ruiz et al. 2017 - SuÁrez-Ruiz, I., VAlentim, B., Borrego, A.G., Bouzinos, A., Flores, D., KALAITZIDIS, S., MALINCONICO, M.L. et al. 2017. Development of a petrographic classification of fly-ash components from coal combustion and co-combustion. (An ICCP Classification System, FlyAsh Working Group - Commission III). International Journal of Coal Geology 183, pp. 188-203. DOI:https://doi.org/10.1016/j.coal.2017.06.004.

WBA. 2018. WBA Global Bioenergy Statistics 2018. World Bioenergy Association. DOI: 10.1016/0165232X(80)90063-4. 


\section{Jakość pelletu drzewnego stosowanego w automatycznych kotłach klasy 5 z Ecodesign na rynku detalicznym w kontekście ochrony powietrza w Polsce}

\section{Streszczenie}

Pellet drzewny, potocznie nazywany biomasą, staje się coraz bardziej dostępnym paliwem stosowanym w ogrzewnictwie i ciepłownictwie w krajach Unii Europejskiej, jak również w Polsce. Jego zastosowanie w kotłach grzewczych posiadających 5. klasę lub/i świadectwo Ecodesign umożliwia indywidualnemu konsumentowi wykorzystanie energii pochodzącej ze źródeł odnawialnych, zmniejszenie uciążliwości dla środowiska poprzez redukcję emisji szkodliwych związków do powietrza oraz zapewnia poczucie komfortu użytkowania poprzez automatyzację obsługi urządzenia grzewczego. W artykule przedstawiono bieżącą sytuację na światowym rynku pelletu drzewnego, opisano podstawowe standardy jakości obowiązujące dla tego paliwa podczas produkcji oraz wskazano trudności w realizacji programów dofinansujących wymianę starych kotłów węglowych na kotły automatyczne 5. klasy na biomasę. Badania prezentowane w niniejszej publikacji ukazują problem, jakim jest obecność niedozwolonych zanieczyszczeń zarówno w certyfikowanym pellecie DIN Plus, EN Plus A1 jak i takim, który tego certyfikatu nie posiada. Badania te dowodzą, że stosowanie pelletów drzewnych, w których zastosowano niedozwolone substancje, wpływają negatywnie na pracę kotła, powodują powstawanie twardych spieków żużlowych i wprowadzają szkodliwe związki do atmosfery powodując, że to paliwo staje się nieekologiczne.

SŁOWA KLUCZOWE: biomasa, pellet drzewny, jakość pelletu, kotły 5. klasy 